\title{
Legal Nature of Public Medical Services Contract
}

\author{
Hanna V Kolisnykova* and Oksana V Lekhkar \\ Department of Civil Law, Yaroslav Mudryi National Law University, Ukraine
}

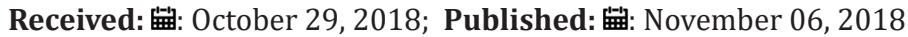

*Corresponding author: Hanna V Kolisnykova, Department of Civil Law №2, Yaroslav Mudryi National Law University, Yaroslav the Wise, Ukraine

Abstract

The topic of the research derives from recognition of the health of the individual as the highest social value of the European community, the search for effective mechanisms for regulating health care relationships in order to achieve the highest level of health for all human beings, improving the quality of life in general and health care in particular.

Keywords: Medical Care; Public Medical Services Contract; Protection of Patients' Right; Medical Declaration

\section{Introduction}

The World Health Organization declares that the possession of the highest achievable standard of health is one of the fundamental rights of every human being. Health is a state of complete physical, mental and social well-being and not merely the absence of disease or infirmity [1]. The number similar provisions are extrapolated also in the national legislation of Ukraine, in particular in the Constitution of Ukraine and the Fundamentals of the Ukrainian legislation on health care [2]. Fundamentals of Health Care Legislation: Law of Ukraine No. 2801-XII of 19.11.1992 [3].

On October 19, 2017, the long-awaited Law “On State Financial Guarantees for Medical Care of the Population" was adopted in Ukraine, which in fact was the initial medical reform [4]. The law under discussion radically changes the principles of providing medical services in Ukraine. These changes reflect Ukraine's perceptions of the world trends that are inherent in the European community. It is a question of increasing the proportion of privatelaw methods of regulation of healthcare relations and the general expansion of dispositive principles in medical law, as opposed to the administrative levers of the Soviet era.

\section{Materials and Methods}

In scientific circles, for a long time now, there is a discussion of the nature of the relations that arise with regard to the provision of medical services. And if in the part where the participants are private entities providing medical services on the basis of civil contracts, the opinion on the private-legal nature of the relations that arises between the patient and the doctor / the medical institution is generally accepted, then in cases where the medical services are provided by a public health care institution for public funds, the opinions of scientists are divergent. Some researches of them consider medical law as a social right (sub-branch of social security law), others claim that it is a sub-branch of administrative law, while others argue the existence of a complex industry medical / medical / healthcare law [5]. The nature of relations in the field of providing medical services with the participation of public institutions has its own characteristics and needs detailed research.

\section{Results and Discussion}

The medical reform in Ukraine is based on the introduction of the principle of "money following the patient," and, therefore, the state undertakes to deliver a certain range of medical services for the state budget, and all other services are provided by state medical institutions on a contractual basis, the payment for which the patient carries on his own. To this end, the state through a specially authorized body - the National Health Service of Ukraine (NSZU) on a competitive basis concludes a special contract with medical organizations, under which the latter undertake to provide medical services under the program of medical guarantees to patients, and the customer (NSZU) pays such services in accordance with the established tariff and correction coefficients [6]. By its legal nature, this contract is an agreement in favour of a third person the immediate patient to whom the service is provided. The patient receives the status of a third person under the agreement after signing the relevant declaration. The legal nature of this declaration needs to be clarified.

The essence of the declaration is to establish the will of the patient to consent to obtain the medical services provided by a 
particular medical institution and the choice of the immediate provider of service, that is a doctor. Thus, the above declaration confirms the establishment of contractual relations between the medical institution and the patient, regardless of the form in which such an agreement is concluded, either verbally or in writing. The practice of concluding numerous contracts shows that public medical institutions of Ukraine usually conclude oral contracts for the provision of medical services, while private institutions choose written agreements. As soon as the parties enter into the contract their relations, including all the rules, rights and obligations, are regulated under both civil and special legislation and the procedure of medical activity in Ukraine, apply.

The contract for the provision of medical services has its own characteristics, due to the special trusting relations between its parties (so-called fiduciary transaction). The parties to the contract are a professionally trained servant who has special knowledge and skills, and a patient who does not have such knowledge, therefore, has the right to choose a medical facility and his/her doctor and trust him/her or choose another in the event of a loss of confidence, but is not entitled to interfere in the procedure for the provision of medical services by a doctor.

\section{Conclusion}

Thus, we can state that in the scientific discussion about the nature of the relationship with the provision of medical services there are more arguments in favour of their civilized nature, based on which the contract, regardless of the mechanism of their financing at the expense of the state or the patient. With the introduction of medical reform in Ukraine, the volume of medical services regulated by civil rather than public law [7] is expanding considerably. The indicated above is evidence of the increase in the proportion of public participation in civil relations, based on the principles of legal equality, free expression of will, property independence and freedom of contract.

\section{References}

1. Constitution of WHO: principles.

2. Bulletin of the Verkhovna Rada of Ukraine (1996) Constitution of Ukraine.

3. Fundamentals of Ukrainian Health Law (1993) The law of Ukraine.

4. Law of Ukraine (2018) On state financial guarantees of Public health care.

5. Maidanyk R (2010) Treaty on the provision of medical services.

6. Cabinet of Ministers of Ukraine Resolution (2018) Some questions about contracts for medical care of the population under the program of medical guarantees.

7. The civil code of Ukraine 2003.
ISSN: 2574-1241

DOI: 10.26717/BJSTR.2018.10.002009

Hanna V Kolisnykova. Biomed J Sci \& Tech Res

(C) This work is licensed under Creative Commons Attribution 4.0 License

Submission Link: https://biomedres.us/submit-manuscript.php

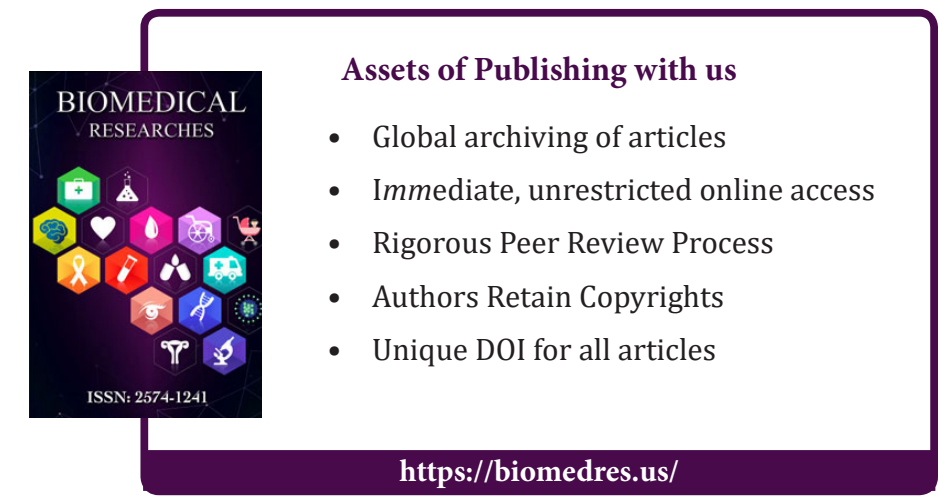

